\title{
Genetic Variability of Grapevine Pinot gris virus and Its Association with Grapevine Leaf Mottling and Deformation
}

\author{
P. Saldarelli, A. Giampetruzzi, M. Morelli, U. Malossini, C. Pirolo, P. Bianchedi, and V. Gualandri
}

First, second, third, and fifth authors: CNR Istituto per la Protezione Sostenibile delle Piante, UOS-Bari, and Dipartimento di Scienze del Suolo della Pianta e degli Alimenti, Università degli Studi di Bari via Amendola 165/A, 70126, Bari, Italy; and fourth, sixth, and seventh authors: FEM-IASMA, Centre for Technology Transfer, via E. Mach 1, 38010, San Michele all'Adige (Trento), Italy.

Accepted for publication 1 November 2014.

\begin{abstract}
Saldarelli, P., Giampetruzzi, A., Morelli, M., Malossini, U., Pirolo, C., Bianchedi, P., and Gualandri, V. 2015. Genetic variability of Grapevine pinot gris virus and its association with grapevine leaf mottling and deformation. Phytopathology 105:555-563.

The role of Grapevine Pinot gris virus (GPGV) in the etiology of grapevine leaf mottling and deformation was investigated by biological and molecular assays. A survey on different cultivars from the Trentino Region in Italy showed a widespread distribution of GPGV, which was associated with symptomatic (79\%) but also with symptomless $(21 \%)$ vines. Symptomatic and GPGV-infected 'Pinot gris' vines induced symptoms on grafted vines of healthy Pinot gris or 'Traminer', whereas GPGV-infected but symptomless vines did not. High-throughput sequencing of small RNA (sRNA) populations of two infected Pinot gris accessions confirmed the existence of nearly

overlapping viromes in vines with or without symptoms but phylogenetic analyses of the genomes of seven GPGV isolates from Italy and the Czech and Slovak Republics clearly differentiated those infecting symptomatic vines. The involvement of Grapevine rupestris vein feathering virus (GRVFV) in the disease, which was only infecting the symptomatic vine, was ruled out by reverse-transcription polymerase chain reaction studies. Maximum likelihood and Bayesian phylogenetic analysis of two GPGV genomic regions, encompassing part of the movement protein (MP) and coat protein gene sequences and the RNA-dependent RNA polymerase domain of the replicase gene, showed that isolates from symptomatic vines form a lineage distinct from that of symptomless vines. Moreover, the presence or lack of the MP stop codon identified in viral isolates from symptomatic or symptomless vines, respectively, is likely responsible for an MP six amino acids longer in symptomless isolates.
\end{abstract}

Symptoms of stunting, chlorotic mottling, and leaf deformation had been observed on Vitis vinifera 'Pinot gris', in Trentino vineyards since 2003. After several clostero-, ampelo-, nepo-, and vitiviruses were excluded as possible causes for these symptoms, a metagenomic investigation using a next-generation sequencing (NGS) approach was undertaken to determine the etiology. This led to the identification of a new trichovirus, Grapevine Pinot gris virus (GPGV), whose full-length sequence was described and shown to be closely related to that of Grapevine berry inner necrosis virus (GINV) (7,15). Similar symptoms were later reported from Emilia Romagna (http://archives.eppo.int/EPPOReporting/2014/ Rsf-1401.pdf) in 'Chardonnay' from Trentino (14), Friuli Venezia Giulia (13) from 'Traminer' and 'Pinot noir', and Apulia in 'Black Magic' and 'Supernova' table grape (18). The virus was also detected in Veneto (22) in 'Glera' and in Slovenia (20) in Pinot gris, 'Sauvignonasse', and 'Muscat blanc'. In Slovenia, GPGV-like symptoms are widely spread, with 40 of 42 symptomatic vines (all which tested negative from the main grapevine nepoviruses) being infected by GPGV (20). Outside of Europe, GPGV was found in Korea (2) on the table grape 'Tamnara', which showed symptoms of berry necrosis similar to those described for the related virus GINV (27). GPGV was also detected in the Czech and Slovak Republics, where the complete genome of three additional isolates was determined (8). These isolates have a low nucleotide sequence heterogeneity and differ from the Italian isolate because of localized

Corresponding author: P. Saldarelli; E-mail address: p.saldarelli@ba.ivv.cnr.it

*The $\boldsymbol{e}$-Xtra logo stands for "electronic extra" and indicates that two supplementary figures, one supplementary table, and one supplementary file are published online.

http://dx.doi.org/10.1094/PHYTO-09-14-0241-R

(C) 2015 The American Phytopathological Society divergences within the open reading frame (ORF)1 amino acid sequence, which could result from events of recombination with GINV. In addition, a random survey on a set of Slovak and Czech grapevine accessions resulted in GPGV detection in 13 of 58 vines; however, the specific symptoms associated with the presence of the virus were not observed because these vines hosted multiple viruses (8).

A 3-year field study showed that vines affected by the GPGVassociated disease had fewer canes and a lower number and weight of the bunches (14).

All mentioned reports show that, wherever it occurs in Europe, the association of GPGV with symptoms is contradictory, a feature noticed since its discovery (7), that disclosed the frequent presence of a latent behavior.

In the present study, a survey was carried out on a group of 92 GPGV isolates from Trentino to assess the virus-symptom association. Biological indexing of symptomless and symptomatic Pinot gris vines was performed and the viromes of two vines, with or without symptoms, were analyzed by sequencing their small RNAs (sRNAs). This allowed the assemblage of GPGV genome consensus sequences, which were phylogenetically compared with full-length genomes available in databases. Moreover, the genetic diversity among GPGV isolates was investigated in two genome regions, the first encompassing part of the movement protein (MP) and coat protein $(\mathrm{CP})$ sequences and the second corresponding to the RNAdependent RNA polymerase (RdRp) domain of the replicase gene. Collectively, the results suggest that GPGV exists as a population of genetically distinct virulent and latent isolates.

\section{MATERIALS AND METHODS}

Plant sources and grafting assays. In this study, 100 grapevine accessions were analyzed (Table 1), 92 of which, 
originating from different Trentino vineyards, were selected based on the presence or absence of symptoms. Pinot gris accessions ZA505-1A and ZA505-2 $\mathrm{N}$ were previously investigated by Giampetruzzi et al. (7), whereas ZA505-2A (symptomatic) and ZA505-1 N (symptomless) were the source of the sRNA populations analyzed in the present work. Dormant canes were collected from these vines from 2010 to 2014 and from infected Black Magic and Supernova table grape (18).

Biological assays were performed by bud and green grafting (25). During 2009, dormant cuttings from symptomatic or symptomless Pinot gris vines were rooted in pots, then grafted with buds from healthy V. rupestris 'St. George' and V. vinifera 'Cabernet franc',
Pinot gris, and Traminer. After 1 year, successful grafts were transferred to the field and symptoms were scored in 2010 and 2014. Green grafting was done in 2014 as described by Taylor et al. (26). Grafted plants were maintained in a greenhouse and scored for symptoms in the same year.

RNA extraction, reverse-transcription polymerase chain reaction, and synthesis of $\mathbf{S R N A}$ libraries. For GPGV detection by reverse-transcription polymerase chain reaction (RT-PCR), total RNAs were purified from $100 \mathrm{mg}$ of cortical scrapings using the RNeasy Plant Mini Kit (Qiagen, The Netherlands), as described by MacKenzie et al. (12). Detection of relevant grapevine viruses associated with leafroll (Grapevine leafroll associated virus-1, -2,

TABLE 1. Grapevine samples analyzed in the present study ${ }^{\mathrm{a}}$

\begin{tabular}{|c|c|c|c|c|c|c|c|}
\hline Cultivar & Place of sampling ${ }^{\mathrm{b}}$ & Sample ID & GPGV & Symptoms & Sequence & Viruses $^{\mathrm{c}}$ & Year of sampling \\
\hline Pinot gris & Zablani & ZA505-1A & + & + & RdRp, MP/CP & GRSPaV, GSyV-1, HSVd, GYSVd-1 & 2010 \\
\hline Pinot gris & Zablani & ZA505-2A & + & + & RdRp, MP/CP & GRSPaV, GRVFV, HSVd, GYSVd-1 & 2013 \\
\hline Pinot gris & Zablani & ZA505-1N & + & - & RdRp, MP/CP & GRSPaV, HSVd, GYSVd-1 & 2013 \\
\hline Pinot gris & Zablani & ZA505-2N & + & - & $\mathrm{RdRp}, \mathrm{MP} / \mathrm{CP}$ & $\begin{array}{c}\text { GRSPaV, GRVFV, GSyV-1, HSVd, } \\
\text { GYSVd-1 }\end{array}$ & 2010 \\
\hline Traminer & Filippi & FI5A & + & + & & GRSPaV & 2013 \\
\hline Traminer & Filippi & FI5N & - & - & $\ldots$ & GRSPaV, GFkV & 2013 \\
\hline Pinot gris & S. Donà & SD7-3-6A & + & + & $\ldots$ & GRSPaV & 2013 \\
\hline Pinot gris & S. Donà & SD8-8-9A & + & + & $\ldots$ & GRSPaV, GFkV & 2013 \\
\hline Traminer & Navesel & NAV9161N & - & - & $\ldots$ & GRSPaV & 2013 \\
\hline Traminer & Navesel & NAV9181N & + & - & RdRp, MP/CP & GRSPaV & 2013 \\
\hline Pinot gris & Navesel & NAV5051N & + & - & $\ldots$ & GRSPaV & 2013 \\
\hline Pinot gris & Navesel & NAV5141N & - & - & $\ldots$ & GRSPaV & 2013 \\
\hline Pinot noir & Navesel & NAV1911N & - & - & $\ldots$ & GRSPaV & 2013 \\
\hline Pinot noir & Navesel & NAV1851N & + & + & $\ldots$ & GRSPaV, GLRaV-3 & 2013 \\
\hline Pinot noir & Navesel & NAV2011N & + & - & $\ldots$ & GRSPaV, GLRaV-3 & 2013 \\
\hline Pinot gris & Paoli & PA505v.2N & + & + & $\ldots$ & GRSPaV & 2013 \\
\hline Pinot gris & Paoli & PAv514v.2N & + & + & $\ldots$ & GRSPaV & 2013 \\
\hline Pinot gris & Zablani & ZA505-4N & + & - & $\ldots$ & GRSPaV & 2013 \\
\hline Pinot gris & Zablani & ZA505-3N & + & - & RdRp, MP/CP & GRSPaV & 2013 \\
\hline Pinot gris & Zablani & ZA505-10N & + & + & $\mathrm{MP} / \mathrm{CP}$ & GRSPaV & 2013 \\
\hline Pinot gris & S. Donà & SD4-4-6A & + & + & $\ldots$ & GRSPaV & 2013 \\
\hline Pinot gris & S. Donà & SD2-12-4 A & + & + & $\ldots$ & GRSPaV & 2013 \\
\hline Traminer & Navesel & NAV916-2N & - & - & $\ldots$ & GRSPaV & 2013 \\
\hline Traminer & Navesel & NAV916-3N & - & - & $\ldots$ & GRSPaV & 2013 \\
\hline Traminer & Navesel & NAV918-2N & - & - & $\ldots$ & GRSPaV & 2013 \\
\hline Traminer & Navesel & NAV918-3N & + & + & $\ldots$ & GRSPaV & 2013 \\
\hline Pinot gris & Navesel & NAV $505-2 \mathrm{~N}$ & - & - & $\ldots$ & GRSPaV & 2013 \\
\hline Pinot gris & Navesel & NAV514-2N & - & - & $\ldots$ & GRSPaV & 2013 \\
\hline Pinot noir & Navesel & NAV191-2N & + & + & $\ldots$ & GRSPaV, GFkV & 2013 \\
\hline Pinot noir & Navesel & NAV185-2N & + & + & $\ldots$ & GRSPaV, GFkV & 2013 \\
\hline Pinot noir & Navesel & NAV201-2N & - & - & $\ldots$ & GRSPaV & 2013 \\
\hline Pinot gris & Zablani & ZA505-3A & + & + & $\mathrm{RdRp}$ & GRSPaV, GFkV & 2011 \\
\hline Pinot gris & Zablani & ZA505-4A & + & + & $\ldots$ & GFkV, GRSPaV & 2013 \\
\hline Pinot gris & Zablani & ZA505-5A & + & + & RdRp, MP/CP & GRSPaV & 2011 \\
\hline Pinot gris & Zablani & ZA505-6A & + & + & $\mathrm{MP} / \mathrm{CP}$ & GRSPaV & 2013 \\
\hline Pinot gris & Zablani & ZA505-7A & + & + & $\mathrm{MP} / \mathrm{CP}$ & GRSPaV & 2013 \\
\hline Pinot gris & Zablani & ZA505-8A & + & + & RdRp, MP/CP & GRSPaV & 2013 \\
\hline Pinot gris & Zablani & ZA505-9A ${ }^{d}$ & + & + & RdRp, MP/CP & GRSPaV & 2011,2013 \\
\hline Pinot gris & Zablani & ZA505-5N & + & - & $\ldots$ & GRSPaV, GFkV & 2013 \\
\hline Pinot gris & Zablani & ZA505-6N & + & - & $\mathrm{MP} / \mathrm{CP}$ & GRSPaV & 2013 \\
\hline Pinot gris & Zablani & ZA505-7N & + & - & $\mathrm{MP} / \mathrm{CP}$ & GRSPaV & 2013 \\
\hline Pinot gris & Zablani & ZA505-8N & + & - & $\mathrm{MP} / \mathrm{CP}$ & GRSPaV & 2013 \\
\hline Pinot gris & Zablani & ZA505-9N & + & - & $\mathrm{MP} / \mathrm{CP}$ & GRSPaV & 2011 \\
\hline Traminer & Filippi & FI1A & + & + & $\ldots$ & GFkV, GRSPaV & 2013 \\
\hline \multirow[t]{2}{*}{ Traminer } & Filippi & FI2A & + & + & $\ldots$ & GRSPaV & 2013 \\
\hline & & & & & & (con & inued on next page \\
\hline
\end{tabular}

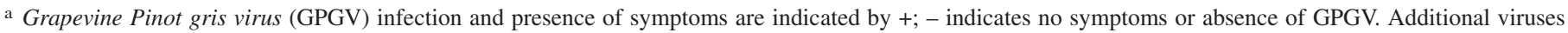
detected in each sample are reported. The "Sequence" column specifies the isolates used for cloning and sequencing the corresponding movement protein and coat protein (MP/CP) and RNA-dependent RNA polymerase (RdRp) sequences.

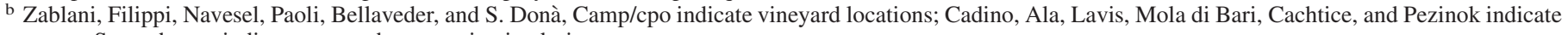
towns; Screenhouse indicates screenhouse-maintained vines.

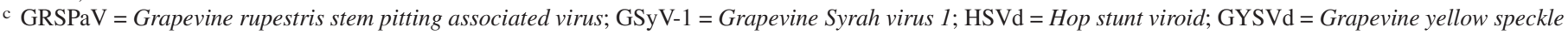
viroid; GRSPaV = Grapevine rupestris stem pitting associated virus; GRVFV = Grapevine rupestris vein feathering virus; GFkV = Grapevine fleck virus; GLRaV-1, -2, and -3 = Grapevine leafroll associated virus-1, -2, and -3, respectively; GFLV = Grapevine fanleaf virus; ArMV = Arabis mosaic virus.

d Retested in 2011 and 2013 only for MP/CP.

e 505 VASO A grafted on ZA505-1A.

$\mathrm{f}$ Multiple infection. 
and -3), rugose wood (Grapevine virus $A$ and Grapevine virus B), infectious degeneration (Grapevine fanleaf virus and Arabis mosaic virus), and Grapevine fleck virus (GFkV) was done by multiplex RT-PCR as reported (6), whereas primers and the protocol for Grapevine rupestris stem pitting associated virus (GRSPaV) were described by Meng et al. (17). DNA fragments corresponding to part of the MP/CP and RdRp gene domains were amplified from total RNA after random-primed reverse transcription by Moloney murine leukemia virus reverse transcription (Thermo Fisher Scientific, USA). Resulting cDNA was subjected to PCR with two sets of GPGV primers selected by Primer-BLAST, which allows the evaluation of unspecific matching to the $V$. vinifera genome. Primers designed on the $3^{\prime}$ end of the MP and the $5^{\prime}$ end of the viral CP (MP/CP) gene sequences, DetF (5'-TGGTCTGCAGCCAGGGGACA-3') and DetR (5'-TCACGACCGGCAGGGAAGGA-3'), were already described (18), whereas GPGVRepF (5'-TGAGGCATTCGATGTTT CCCA-3') and GPGVRepR (5'-ACCCAATCAAGCCATGAACCT$3^{\prime}$ ) were designed to target the RdRp domain of the GPGV replicase gene. For both sets of primers, PCR was performed in $1 \times$ PCR buffer containing $2.5 \mathrm{mM} \mathrm{MgCl} 2,0.2 \mathrm{mM}$ dNTPs, $0.2 \mu \mathrm{M}$ each primer, 0.0375 U of Dream Taq DNA polymerase (ThermoFisher Scientific), and the following cycling conditions: initial denaturation at $94^{\circ} \mathrm{C}$ for $2 \mathrm{~min}$; followed by 30 cycles at $94^{\circ} \mathrm{C}$ for $30 \mathrm{~s}, 60^{\circ} \mathrm{C}$ for $40 \mathrm{~s}$, and $72^{\circ} \mathrm{C}$ for $45 \mathrm{~s}$; and a final extension at $72^{\circ} \mathrm{C}$ for $7 \mathrm{~min}$. Grapevine rupestris vein feathering virus (GRVFV) was detected by RT-PCR with four different sets of primers: VF-F 5'-CGAAGCTCACTGGCG GACTTCTG-3', VF-R 5'-GGCACAGAAGCCAAGGCGTTCA-3 (S. Sabanadzovic, personal communication); C105F1 5'-CCTGTCG CTTCCTTCTCATCT-3', C105R2 5'-CATCTTCCATGCCCATTT CTTG-3' (M. Al Rwahnih, personal communication); GRVFV2801

TABLE 1. (continued from preceding page)

\begin{tabular}{|c|c|c|c|c|c|c|c|}
\hline Cultivar & Place of sampling ${ }^{b}$ & Sample ID & GPGV & Symptoms & Sequence & Viruses $^{c}$ & Year of sampling \\
\hline Traminer & Filippi & FI3A & + & + & $\mathrm{MP} / \mathrm{CP}$ & GFkV, GRSPaV & 2013 \\
\hline Traminer & Filippi & FI4A & + & + & $\mathrm{MP} / \mathrm{CP}$ & GRSPaV & 2013 \\
\hline Traminer & Filippi & FI6AV & + & + & $\mathrm{MP} / \mathrm{CP}$ & GRSPaV & 2013 \\
\hline Traminer & Filippi & FI7AV & + & + & $\mathrm{MP} / \mathrm{CP}$ & GFkV & 2013 \\
\hline Traminer & Filippi & FI8AV & + & + & $\mathrm{MP} / \mathrm{CP}$ & $\ldots$ & 2013 \\
\hline Traminer & Filippi & FI1N & - & - & $\ldots$ & GFkV, GRSPaV & 2013 \\
\hline Traminer & Filippi & FI2N & + & - & $\ldots$ & $\ldots$ & 2013 \\
\hline Traminer & Filippi & FI3N & + & - & $\ldots$ & GRSPaV & 2013 \\
\hline Traminer & Filippi & FI4N & + & - & $\mathrm{MP} / \mathrm{CP}$ & GRSPaV & 2013 \\
\hline Traminer & Filippi & FI6NV & - & - & $\ldots$ & $\ldots$ & 2013 \\
\hline Traminer & Filippi & FI7NV & - & - & $\ldots$ & GFkV, GRSPaV & 2013 \\
\hline Traminer & Filippi & FI8NV & - & - & $\ldots$ & $\ldots$ & 2013 \\
\hline Traminer & Filippi & FI9NV & + & + & $\ldots$ & GFkV, GRSPaV & 2013 \\
\hline Vitis riparia & Screenhouse & VASO C & - & - & $\ldots$ & GRSPaV & 2012 \\
\hline Traminer & Screenhouse & 916VASO A & - & - & $\ldots$ & GRSPaV & 2012 \\
\hline Traminer & Screenhouse & 918VASO A & + & + & $\ldots$ & GRSPaV & 2012 \\
\hline Pinot gris & Screenhouse & 505VASO A & - & - & $\ldots$ & GRSPaV & 2012 \\
\hline Pinot gris & Camp/cpo & 513 VM 5N & + & + & $\ldots$ & GRSPaV & 2012 \\
\hline Pinot gris & Zablani (Pancher) & $\mathrm{ZA}(\mathrm{PA}) \mathrm{P} 1$ & + & + & $\mathrm{MP} / \mathrm{CP}$ & $\ldots$ & 2013 \\
\hline Pinot gris & Zablani (Pancher) & ZA(PA)P2 & + & + & $\mathrm{MP} / \mathrm{CP}$ & $\ldots$ & 2013 \\
\hline Pinot gris & Zablani (Pancher) & $\mathrm{ZA}(\mathrm{PA}) \mathrm{P} 3$ & + & + & $\ldots$ & $\ldots$ & 2013 \\
\hline Pinot gris & Zablani (Pancher) & $\mathrm{ZA}(\mathrm{PA}) \mathrm{P} 4$ & + & + & $\mathrm{MP} / \mathrm{CP}$ & $\ldots$ & 2013 \\
\hline Pinot gris & Zablani (Pancher) & $\mathrm{ZA}(\mathrm{PA}) \mathrm{P} 5$ & + & + & $\ldots$ & GRSPaV & 2013 \\
\hline Pinot gris & Cadino (Faedo Endrizzi) & $\mathrm{CAD}(\mathrm{FE}) \mathrm{P} 1$ & + & + & $\ldots$ & GRSPaV & 2013 \\
\hline Pinot gris & Cadino (Faedo Endrizzi) & $\mathrm{CAD}(\mathrm{FE}) \mathrm{P} 2$ & + & + & $\ldots$ & GRSPaV, GFkV & 2013 \\
\hline Pinot gris & Cadino (Faedo Endrizzi) & CAD(FE)P3 & + & + & $\ldots$ & GRSPaV & 2013 \\
\hline Pinot gris & Cadino (Faedo Endrizzi) & $\mathrm{CAD}(\mathrm{FE}) \mathrm{P} 4$ & + & + & $\ldots$ & GRSPaV & 2013 \\
\hline Pinot gris & Cadino (Faedo Endrizzi) & CAD(FE)P5 & + & + & $\ldots$ & GFkV & 2013 \\
\hline Pinot gris & Lavis (Gottardi) & LA(GO)P1 & + & + & $\ldots$ & GRSPaV & 2013 \\
\hline Pinot gris & Lavis (Gottardi) & $\mathrm{LA}(\mathrm{GO}) \mathrm{P} 2$ & + & + & $\ldots$ & GRSPaV & 2013 \\
\hline Pinot gris & Lavis (Gottardi) & $\mathrm{LA}(\mathrm{GO}) \mathrm{P} 3$ & + & + & $\ldots$ & $\ldots$ & 2013 \\
\hline Pinot gris & Lavis (Gottardi) & LA(GO)P4 & + & + & $\ldots$ & GRSPaV, GFkV & 2013 \\
\hline Pinot gris & Lavis (Gottardi) & LA(GO)P5 & + & + & $\mathrm{MP} / \mathrm{CP}$ & GFkV & 2013 \\
\hline Traminer & Bellaveder (Faedo) & $\mathrm{BE}(\mathrm{FA}) \mathrm{P} 1$ & + & + & $\ldots$ & GVA & 2013 \\
\hline Traminer & Bellaveder (Faedo) & $\mathrm{BE}(\mathrm{FA}) \mathrm{P} 2$ & + & + & $\mathrm{MP} / \mathrm{CP}$ & $\ldots$ & 2013 \\
\hline Traminer & Bellaveder (Faedo) & $\mathrm{BE}(\mathrm{FA}) \mathrm{P} 3$ & + & + & $\ldots$ & $\ldots$ & 2013 \\
\hline Traminer & Bellaveder (Faedo) & $\mathrm{BE}(\mathrm{FA}) \mathrm{P} 4$ & + & + & $\mathrm{MP} / \mathrm{CP}$ & $\ldots$ & 2013 \\
\hline Traminer & Bellaveder (Faedo) & $\mathrm{BE}(\mathrm{FA}) \mathrm{P} 5$ & + & + & $\ldots$ & GRSPaV & 2013 \\
\hline Pinot gris & Zablani & ZA6Nclorosi & + & - & RdRp, MP/CP & GRSPaV & 2011 \\
\hline Pinot noir & Bellaveder (Faedo) & $\mathrm{BE}(\mathrm{FA}) 1 \mathrm{~A}$ & + & + & $\ldots$ & GRSPaV & 2011 \\
\hline Merlot & Bellaveder (Faedo) & $\operatorname{MER}(\mathrm{FA}) 1 \mathrm{~A}$ & + & + & RdRp, MP/CP & GRSPaV & 2011 \\
\hline Pinot noir & Bellaveder (Faedo) & $\mathrm{BE}(\mathrm{FA} 59) 1 \mathrm{~A}$ & + & + & RdRp, MP/CP & GRSPaV & 2011 \\
\hline Traminer & Bellaveder (Faedo) & $\mathrm{BE}(\mathrm{ac})$ & + & + & $\mathrm{MP} / \mathrm{CP}$ & GRSPaV & 2011 \\
\hline Traminer & Bellaveder (Faedo) & BE5A & + & + & $\mathrm{MP} / \mathrm{CP}$ & GRSPaV & 2011 \\
\hline Traminer & Ala acari Pozzo basso & ALA-P4 & + & + & $\mathrm{MP} / \mathrm{CP}$ & GRSPaV & 2014 \\
\hline Pinot noir & Bellaveder & PN-SO41A & + & + & $\mathrm{MP} / \mathrm{CP}$ & GRSPaV, GFkV & 2011 \\
\hline Pinot gris & Screenhouse & CLONE505 3T $\mathrm{T}^{\mathrm{e}}$ & + & + & $\mathrm{MP} / \mathrm{CP}$ & $\begin{array}{c}\text { GRSPaV, GRVFV, GSyV-1, } \\
\text { HSVd, GYSVd-1 }\end{array}$ & 2014 \\
\hline Supernova & Mola di Bari & MOLA14 & + & - & $\mathrm{MP} / \mathrm{CP}$ & GRSPaV, GFLV, & 2014 \\
\hline Supernova & Mola di Bari & MOLA10 & + & - & $\mathrm{RdRp}, \mathrm{MP} / \mathrm{CP}$ & GRSPaV, GFkV, GFLV & 2014 \\
\hline Black magic & Mola di Bari & MOLA1 & + & - & RdRp, MP/CP & GRSPaV & 2014 \\
\hline Supernova & Mola di Bari & MOLA6 & + & - & $\mathrm{RdRp}, \mathrm{MP} / \mathrm{CP}$ & GRSPaV, GFkV, GFLV & 2014 \\
\hline Supernova & Mola di Bari & MOLA3 33 & + & - & $\mathrm{RdRp}, \mathrm{MP} / \mathrm{CP}$ & GRSPaV, GFkV, & 2014 \\
\hline Unknown & Cachtice, Slovakia & SK01 & + & - & $\mathrm{RdRp}, \mathrm{MP} / \mathrm{CP}$ & Mult. Inf. ${ }^{f}$ & 2012 \\
\hline Unknown & Cachtice, Slovakia & SK13 & + & - & $\mathrm{RdRp}, \mathrm{MP} / \mathrm{CP}$ & Mult. Inf. ${ }^{f}$ & 2012 \\
\hline Veltliner & Pezinok, Slovakia & SK30 & + & - & $\mathrm{RdRp}, \mathrm{MP} / \mathrm{CP}$ & GFkV, ArMV, GLRaV-1 & 2012 \\
\hline
\end{tabular}


5'-CCTTGACTGCCTCCTCGTCTC-3', GRVFV3506 5'-TCCGA GTCTCCAGCGATCAGC-3' (our sequences, unpublished); and GRVFV5202 5'-GATGACAACACCGATTACAAC-3', GRVFV6439 5'-AATGCCCATTGGGCCAGAGAC-3' (our sequences, unpublished). Amplicons were visualized by standard $1.2 \%$ agarose gel electrophoresis. DNA fragments corresponding to the MP/CP and $\mathrm{RdRp}$ amplicons were ligated to the $\mathrm{pSC}-\mathrm{A}$ amp/kan vector and cloned in Escherichia coli SoloPack competent cells (StrataClone PCR cloning kit; Agilent Technologies, USA). At least three independent cDNA clones per isolate were custom sequenced (Macrogen Europe, The Netherlands). Preliminary DNA data analysis was done with SerialCloner 2.6 (http://serialbasics.free. fr/Serial_Cloner.html).

sRNAs extracted from $1 \mathrm{~g}$ of leaf and petiole tissues of accessions ZA505-2A and ZA505-1 N following selective polyethylene glycol precipitation from total RNAs were used for the synthesis of libraries, as described by Giampetruzzi et al. (7). Libraries were sequenced on an Illumina HiScanSQ apparatus in single-read runs (50 nucleotides [nt] long).

Bioinformatic analysis. sRNA libraries were preprocessed using the UEA sRNA toolkit workbench software (23) to trim the 3' adapter, remove low-quality reads, and filter out reads matching known plant transfer RNAs (tRNAs) or ribosomal RNAs (rRNAs) sequences (Rfam version 10, January 2010). Filtering of reads aligning to the $V$. vinifera genome was done by the Patman program (21), allowing no nucleotide mismatches. Contigs were generated by the de novo assembly software Velvet 1.2.08 (27) using $k$-mer values of 15 and 17. Contig homologies with virus and viroid sequences were obtained by BLASTX and BLASTN (1) search using a virus and viroid RefSeq database (http://www.ncbi.nlm.nih. gov/refseq/) with e value thresholds of $10^{-6}$ and $10^{-4}$, respectively. Short-read alignment toward selected virus and viroid genome sequences (GPGV IT, GenBank accession number NC_015782.1; GPGV SK01, GenBank accession number 543887404; GPGV SK13, GenBank accession number 543887408; GPGV SK30, GenBank accession number 543887400; GRVFV, GenBank accession number 57116481; GRSPaV, GenBank accession 9630737; Grapevine yellow speckle viroid-1 [GYSVd-1], GenBank accession number 323482824; and Hop stunt viroid [HSVd] GenBank accession number11497495) was made with SOAP software (11), allowing up to two nucleotide mismatches.

Whole-genome consensus sequences from GPGV ZA505-2A, ZA505-1 N, and ZA505-2 N (7) isolates (ZA505-2Acons, ZA505-1Ncons, and ZA505-2Ncons) were assembled with Geneious 7.0 (Biomatters
Limited, New Zealand) on the .sam file generated by SOAP and on the GPGV IT or GPGV SK30 reference sequences. Positions with zero coverage (i.e., not covered by any reads) were indicated by the character $\mathrm{N}$, whereas the most frequent base resulting from the alignment of reads to the reference sequence was used (plurality rule).

Consensus sequences from the MP/CP- and $\mathrm{RdRp}$-cloned regions were obtained by the multiple alignment tools of Geneious 7.0 using at least three different recombinant plasmids for each isolate. Nucleotide sequences were aligned with MUSCLE (4) as implemented in MEGA 5.2.2 (24). The evaluation of the best model of nucleotide substitution, phylogenetic tree analysis with the maximum likelihood method, and estimation of the statistical significance of branch order by 1,000 bootstrap resampling of the original alignment were inferred by the same software package. Sequences were analyzed for recombination events by the RDP3 package (16). The existence of a temporal signal in the MP/CP sequence was assessed by Path-O-Gen 1.4 software (http://tree.bio.ed.ac.uk/software/pathogen/). Reliability of phylogenetic reconstruction was assessed by evaluating Bayesian posterior probabilities with BEAST 1.8.0 (3) using the Hasegawa-KishinoYano (HKY) substitution model (9), with a four-category discrete approximation of a $\Gamma$ distribution $(\mathrm{HKY}+\Gamma)$ to take into account among-site heterogeneity, and a relaxed uncorrelated molecular clock. Convergence of all parameters was achieved by running $5 \times 10^{8}$ chains until obtaining an effective sample size $>200$. Posterior probabilities and major evolutionary parameters were estimated by TRACER (http://tree.bio.ed.ac.uk/software/tracer). A maximum clade credibility (MCC) tree was obtained by TREEANNOTATOR (beast.bio.ed.ac.uk), discarding 10\% of trees, whereas FIGTREE (http://tree.bio.ed.ac.uk/software/figtree/) allowed graphical display of the BEAST-generated trees.

\section{RESULTS}

Biological indexing. Indicator species $V$. vinifera Cabernet franc and $V$. rupestris did not show symptoms of leaf mottling and deformation during 4 years of observations when grafted on either symptomatic or symptomless Pinot gris vines (Table 2). Conversely, when Pinot gris or Traminer were used as indicators, symptoms were observed the first year after grafting in almost all grafted combinations in which a symptomatic vine was tested. No symptoms were observed when symptomless Pinot gris vines were indexed on Pinot gris and Traminer (Table 2). It should be pointed out that these assays were initiated in 2009 when GPGV was not yet discovered;

TABLE 2. Summary of the assays of biological indexing ${ }^{\mathrm{a}}$

\begin{tabular}{|c|c|c|c|c|c|}
\hline \multirow[b]{2}{*}{ Rootstock } & \multirow[b]{2}{*}{ Indicator } & \multicolumn{2}{|c|}{2010} & \multicolumn{2}{|c|}{2014} \\
\hline & & $N$ & Symptoms & $N$ & Symptoms \\
\hline \multicolumn{6}{|l|}{ Bud grafting } \\
\hline \multirow{3}{*}{ Pinot gris with symptoms ${ }^{\mathrm{b}}$} & Cabernet f. & 4 & 0 & 3 & 0 \\
\hline & P. gris & 16 & 12 & 13 & 13 \\
\hline & Traminer & 3 & 3 & 1 & 1 \\
\hline P. gris without symptoms ${ }^{\mathrm{c}}$ & Cabernet & 6 & 0 & 5 & 0 \\
\hline \multicolumn{6}{|l|}{ Green grafting } \\
\hline \multirow[t]{2}{*}{ P. gris with symptoms ${ }^{\mathrm{d}}$} & P. gris & NA & NA & 3 & 2 \\
\hline & Traminer & NA & NA & 8 & 8 \\
\hline P. gris without symptoms $\mathrm{e}^{\mathrm{e}}$ & Traminer & NA & NA & 3 & 0 \\
\hline
\end{tabular}


that all tested vines, either symptomless or symptomatic in the field, were infected by GPGV (Tables 1 and 2); and that the virus was always transmitted by grafting, as assessed by RT-PCR. By contrast, the Pinot gris and Traminer vines used as indicators tested negative for GPGV by RT-PCR. Additional green-grafting assays were performed in 2014 using GPGV-infected vines ZA505-1A, ZA5052A, ZA505-1 N, and ZA505-2 N (Table 1), whose sanitary status was defined by NGS analysis of sRNAs populations. Results confirmed bud-grafting assays, because symptoms developed only on indicators grafted on symptomatic vines (Table 2). These findings suggested either that GPGV is not involved in the induction of symptoms and, thus, an unknown pathogen is the etiological agent of the disease, or that virulent and latent strains of GPGV exist.

The viromes of GPGV symptomatic and symptomless vines. To investigate the possible existence of unknown viral or viroid pathogens associated with disease symptoms, sRNA libraries from two additional Pinot gris vines, named ZA505-1 N and ZA505-2A, were constructed and analyzed. Symptomless (ZA505$1 \mathrm{~N}$ ) or symptomatic (ZA505-2A) leaves with petioles were collected in the period of optimal symptom expression (spring 2013). After removing low-complexity and t- or rRNA sequences, $1,970,760$ and $1,933,512$ unique reads 16 to $35 \mathrm{nt}$ long were obtained from vines ZA505-1 N and ZA505-2A, respectively. These corresponded to 8,756,149 (ZA505-1N) and 7,823,623 (ZA505-2A) redundant reads (not shown), with a profile distribution showing the predominance of 21-nt sRNAs and 21/24-nt ratios of 1.75 and 2.32 in ZA505-1 N and ZA505-2A, respectively (Supplementary Figure S1). Alignment toward the $V$. vinifera genome with perfect matches gave $63.7 \%(5,580,976)$ and $61.7 \%$ $(4,826,737)$ matching reads for vines ZA505-1 N and ZA505-2A, respectively (not shown).

De novo assembly of the reads by Velvet with $k$-mer of 15 and 17 gave $6,493 / 2,557$ or $6,254 / 2,326$ contigs from ZA505-1 N and ZA505-2A libraries, respectively (Table 3). BLASTN and BLASTX searches identified a similar number of contigs homologous to GPGV IT (7) and GPGV SK30 (8) in both libraries but their relative distribution toward these virus isolates was different. Particularly, a larger number of contigs from vine ZA5052A (44 and 45 with $k$-mer 15 and 17, respectively) was homologous to the symptomatic GPGV IT isolate, whereas contigs generated from the symptomless vine ZA505-1 N were largely homologous (51 and 31 with $k$-mer 15 and 17, respectively) to the Slovak GPGV SK30 isolate. GRSPaV showed the highest number of contigs (Table 3), whereas similar low number of HSVd and GYSVd-1 contigs were found in both libraries. A striking difference with the previously described virome (7) was the exclusive presence of

TABLE 3. Distribution of contigs with virus and viroid homologies in the sRNA libraries ZA505-1 N and ZA505-2A $\mathrm{A}^{\mathrm{a}}$

\begin{tabular}{|c|c|c|c|c|}
\hline Grapevine accession & ZA5 & $05-1 \mathrm{~N}$ & ZA50 & $05-2 \mathrm{~A}$ \\
\hline$k$-mer & 15 & 17 & 15 & 17 \\
\hline Total number of contigs (N50) & 6,493 & 2,557 & 6,254 & 2,326 \\
\hline Grapevine Pinot gris virus IT & $9(77)$ & $6(176)$ & $44(121)$ & $45(120)$ \\
\hline $\begin{array}{l}\text { Grapevine Pinot gris virus } \\
\text { SK30 }\end{array}$ & $51(64)$ & $31(105)$ & $23(63)$ & $11(92)$ \\
\hline $\begin{array}{l}\text { Grapevine rupestris vein } \\
\text { feathering virus }\end{array}$ & $0(0)$ & $0(0)$ & $70(80)$ & $57(78)$ \\
\hline $\begin{array}{l}\text { Grapevine rupestris stem } \\
\text { pitting associated virus }\end{array}$ & $295(63)$ & $141(71)$ & $223(86)$ & $119(88)$ \\
\hline $\begin{array}{l}\text { Grapevine yellow speckle } \\
\text { viroid } 1\end{array}$ & $11(29)$ & $\begin{array}{r}22(33) \\
9(58)\end{array}$ & $\begin{array}{l}9(51) \\
8(61)\end{array}$ & $\begin{array}{l}3(186) \\
3(145)\end{array}$ \\
\hline Hop stunt viroid & $9(38)$ & $9(58)$ & $8(61)$ & $3(145)$ \\
\hline
\end{tabular}

a De novo-assembling of short reads was performed by Velvet using $k$-mer 15 and 17. Homologies were assessed by BLASTN or BLASTX searches toward a National Center for Biotechnology Information virus and viroid database. Numbers of contigs homologous to the listed viruses and viroids and corresponding N50 values are indicated.
GRVFV-specific contigs in vine ZA505-2A. After this initial search, a dedicated database composed of representative genomes of GPGV, GRSPaV, GRVFV, HSVd, and GYSVd-1 was used to probe ZA505-1 N and ZA505-2A libraries by SOAP, allowing two nucleotide mismatches. These alignments (Supplementary Table S1) showed that a higher number of 18- to 26-nt reads matched the GPGV genome in the symptomless ZA505-1 N vine with respect to the symptomatic ZA505-2A. Moreover, GPGV-homologous reads represented the majority of virus- and viroid-associated reads in both vines, with the only exception of GYSVd-1 in vine ZA505-1 N. As expected, GRVFV-homologous reads were found only in vine ZA505-2A.

In order to verify the possible involvement of GRVFV in disease symptoms, the previously sRNA-sequenced vines (7) ZA505-1A (symptomatic) and ZA505-2 N (symptomless) and the currently investigated ZA505-2A and ZA505-1 N plants were tested by RT$\mathrm{PCR}$ for the presence of this virus. GRVFV primers selected in two different laboratories (M. Al Rwhanih and S. Sabanadzovic, personal communications) failed to detect the virus, likely because of genome variability and limited sequence information available. Therefore, two additional primer sets designed on GRVFV sRNA assembled sequences (19) were tested. The expected 705-nt (set a) and 1,237-nt (set b) fragments were amplified from symptomatic ZA505-2A and symptomless ZA505-2 N vines, respectively (Fig. 1) but not from symptomatic ZA505-1A and symptomless ZA505-1 $\mathrm{N}$ vines. An in-depth analysis of GRVFV reads showed that their number (Table 3 ) is negligible (i.e., 24,586 18-26 redundant reads) as compared with GPGV reads. This was shown by a scarce GRVFV genome coverage $(61 \%)$ and average coverage depth $(13 \times)$ (Supplementary Figure S2). These data suggest a limited GRVFV replication, likely as a result of RNA silencing activity in the tissue analyzed. Because these findings were indicative of an inconsistent association of GRVFV with symptoms, no further attention was paid to this virus.

Collectively, these results ruled out the involvement in disease expression of viruses or viroids other than GPGV, thus supporting the hypothesis that strains of this virus with diverse biological traits existed, in line with data resulting from biological indexing.

Genetic diversity of GPGV isolates. The genome consensus sequences of GPGV isolates ZA505-2A, ZA505-1 N, and ZA505-2 N (ZA505-2Acons, ZA505-1Ncons, and ZA505-2Ncons) were obtained by short-read alignment toward the GPGV IT reference sequence, and phylogenetic relationships were investigated by nucleotide comparisons with GPGV IT and the three Slovak isolates SK30, SK01, and SK13 (8). The good genome coverage (Fig. 2) (average coverage depth of ZA505-2Acons $=51 \times$, ZA505-1Ncons = $70 \times$, and ZA505-2Ncons $=61 \times$ ) of the three consensus sequences, each covering $>98 \%$ of the viral genome, made us confident that a phylogenetic relationship could correctly be established. Maximum likelihood phylogeny, inferred under the HKY model of nucleotide substitution (9), grouped the isolates from symptomatic vines

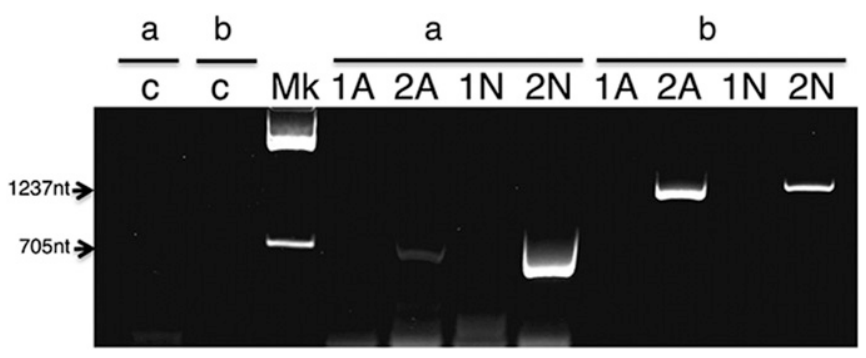

Fig. 1. Grapevine rupestris vein feathering virus detection by reversetranscription polymerase chain reaction (PCR). Amplicons obtained from ZA505-1A (1A), ZA505-2A (2A), ZA505-1 N (1N), and ZA505-2 N (2N) vines using two sets of primers (a) and (b) are separated by gel electrophoresis. DNA molecular weight marker and PCR control without cDNAs are indicated by $(\mathrm{Mk})$ and $(\mathrm{C})$, respectively. 
ZA505-1A and ZA505-2A in a clade strongly supported (100\% of replicates) by bootstrap analysis (Fig. 3). As expected, clustering of the Slovak isolates SK01, SK13, and SK30 is strongly supported, whereas the topology of isolate ZA505-1 N is not clearly defined, although its membership in the clade of symptomless isolates is certain. Results of this analysis suggest that GPGV ZA505-1A and ZA505-2A isolates underwent a selection mechanism that induces symptoms in grapevine. Strikingly, these phylogenetic results mirror those found studying contig homologies, in that a larger number of contigs from vine ZA505-2A align to the symptomatic
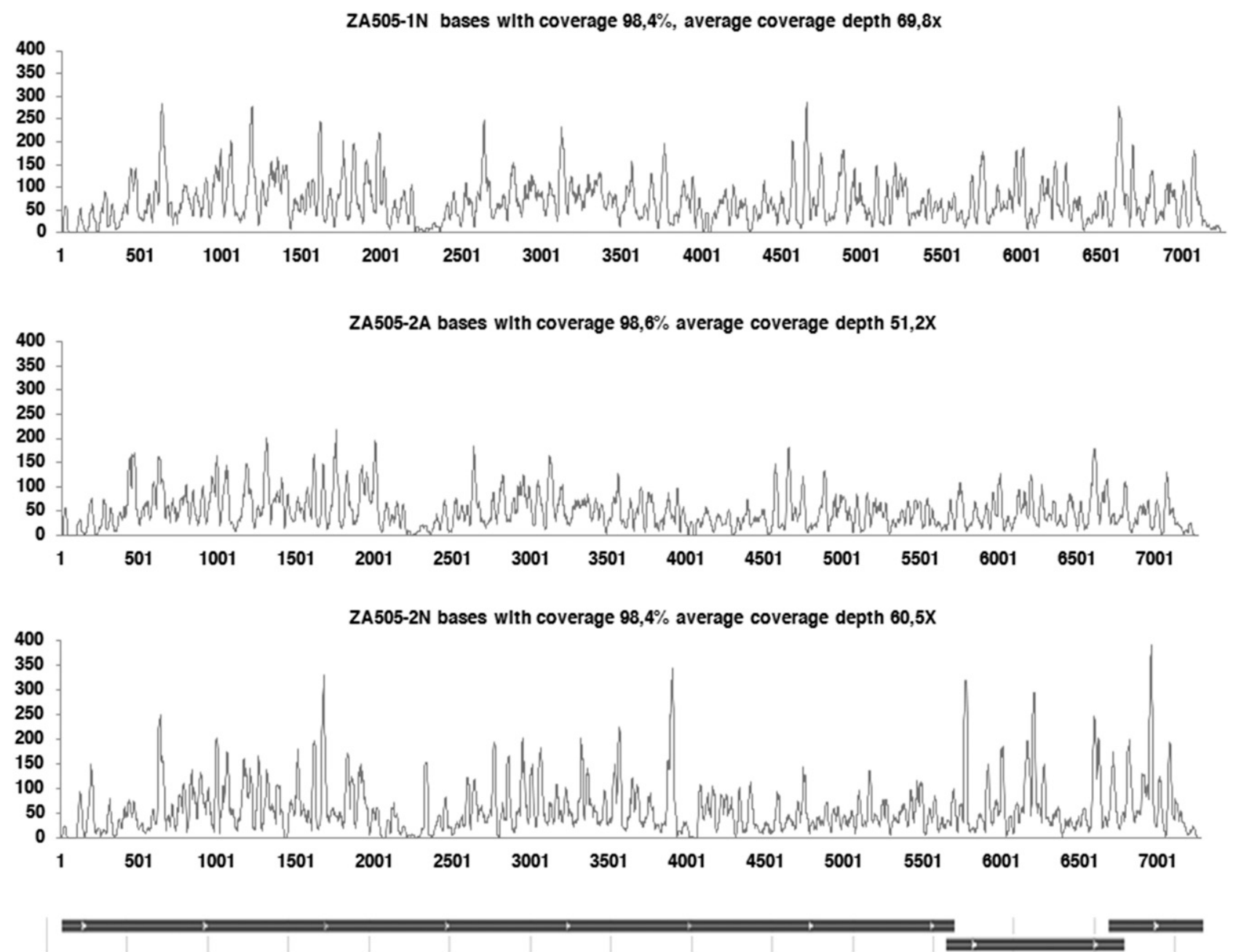

Fig. 2. Graph plots showing the number of 20-24 unique viral sRNAs of ZA505-1 N, ZA505-2A, and ZA505-2 N distribution along the Grapevine Pinot gris virus (GPGV) IT RNA. GPGV genome organization is depicted below the plots. Sense and antisense reads are collapsed above the x-axis, reporting the nucleotide numbering, whereas the y-axis indicates nucleotide coverage. Genome covered bases and average coverage depth are reported.
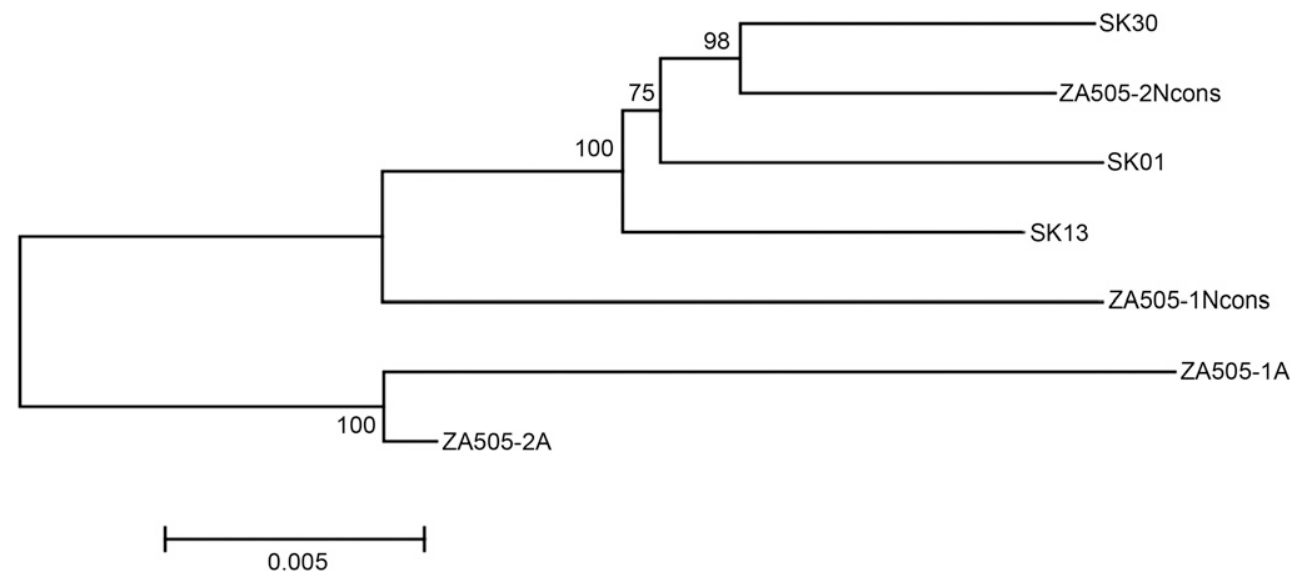

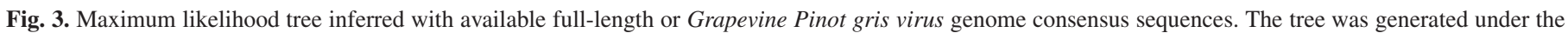

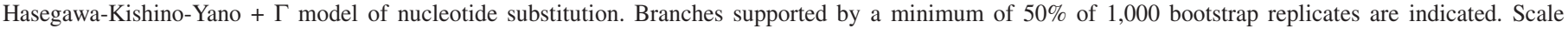
indicates units in nucleotide substitutions per site. 
GPGV IT isolate ZA505-1A, whereas the opposite occurs with contigs generated from the symptomless vine ZA505-1 N, which prevalently matches the Slovak isolate SK30. To rule out the potential bias determined by the reference isolate (ZA505-1A), the same analysis was performed after generating ZA505-2A, ZA505-1 N, and ZA505-2 N consensus sequences toward the GPGV SK30 isolate. A comparable clustering was obtained when phylogeny was determined with these SK30-derived consensus sequences (not shown).

To confirm the existence of genetic differentiation in symptomatic GPGV isolates, two viral genome regions were analyzed, one encompassing the $3^{\prime}$ end of the MP and the $5^{\prime}$ end of the CP genes (MP/CP) and the other the RdRp domain of the replicase gene. Sequences from 45 and $20 \mathrm{MP} / \mathrm{CP}$ and RdRp gene fragments, respectively, of isolates from different grapevine accessions composed of an almost equal number of vines showing symptoms or not, were selected for the analysis (Table 1). The majority of samples, belonging to Pinot gris and Traminer, was collected in different vineyards in Trentino in 2011 to 2014. Of the $45 \mathrm{MP} / \mathrm{CP}$ gene sequences, 37 and 5 were from Trentino and Apulia viral isolates, respectively (18), whereas the 3 Slovak sequences were retrieved from the National Center for Biotechnology Information (NCBI) database (8). Similarly, the group of viral strains from which the RdRp sequences were obtained was composed of 15 Trentino, 2 Apulia, and 3 Slovak isolates, the latter retrieved from the NCBI database. Isolates from Apulia were chosen from symptomless vines and those from the Slovak Republic were also reported as symptomless (8). In order to identify the predominant viral sequence in each accession from Apulia and Trentino, three different plasmids recombinant for the $\mathrm{MP} / \mathrm{CP}$ - or RdRp-amplified regions were sequenced, and a consensus sequence was generated and used for phylogenetic assessment. Nucleic acid sequences determined in this study are available in the EMBL Nucleotide Sequence Database with accession numbers LN606702 to LN606758. No recombination was found using RDP3, allowing us to infer phylogenetic relationships by the maximum likelihood method under the same substitution model as above. The tree generated using MP/CP sequences clearly differentiated isolates from symptomatic grapevines, which was supported in $82 \%$ of bootstrap replicates (Fig. 4A), whereas isolates from symptomless grapevines clustered in two strongly supported clades (98 and $96 \%$ replicates). The same topology, clustering in a well-supported clade ( $83 \%$ bootstrap replicates) all the isolates
A

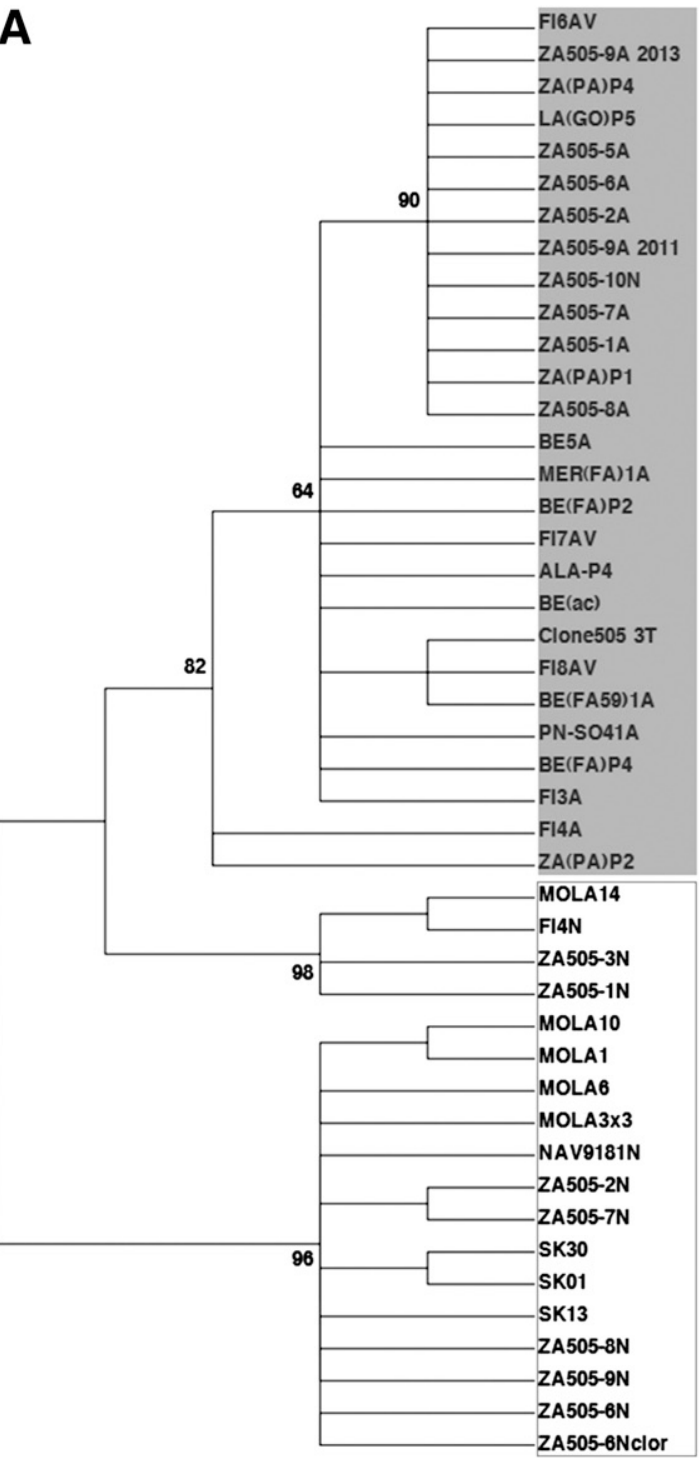

B

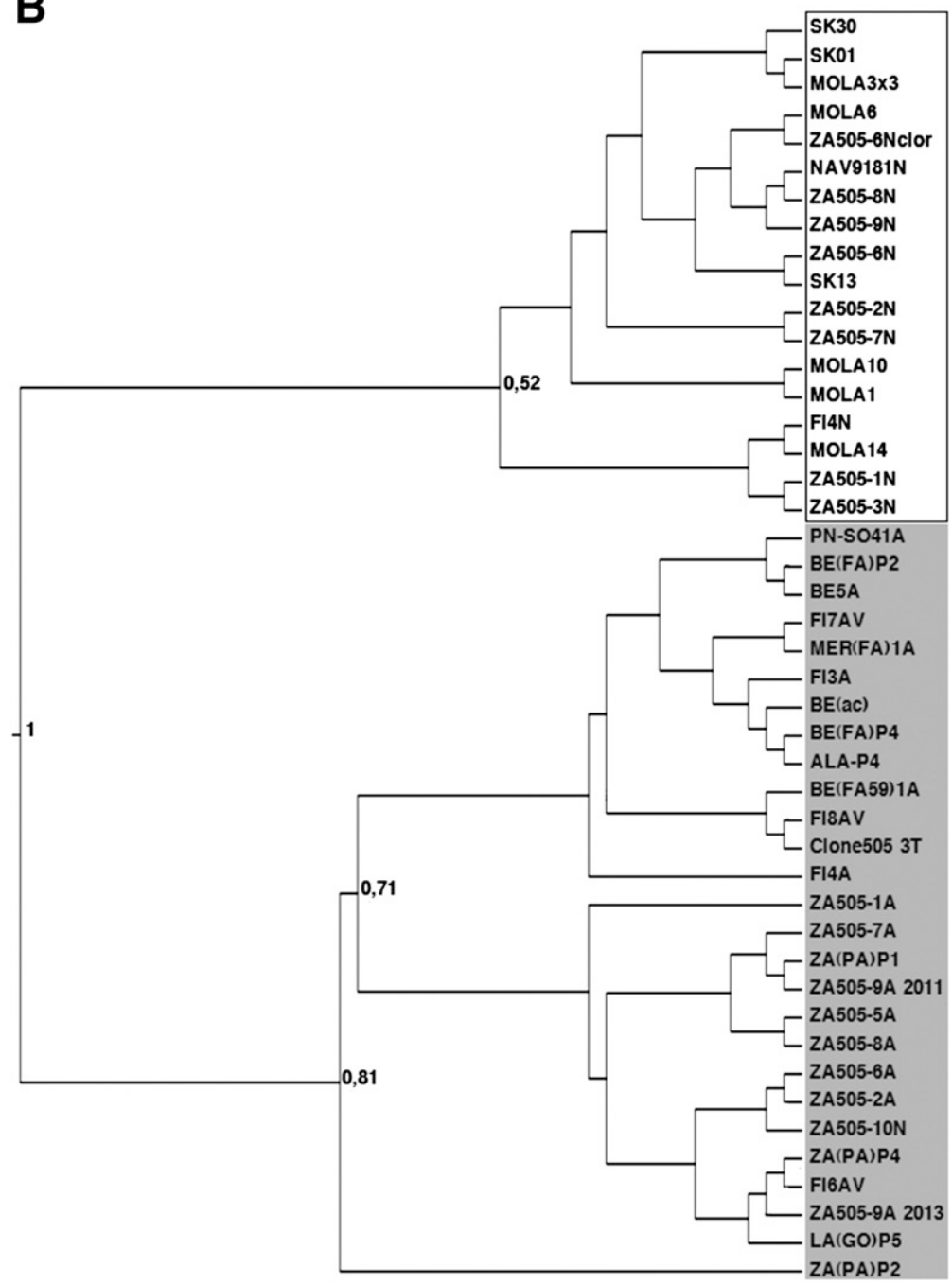

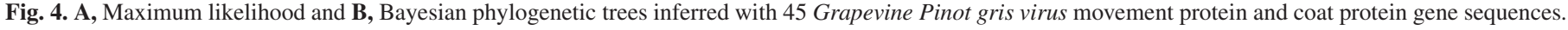

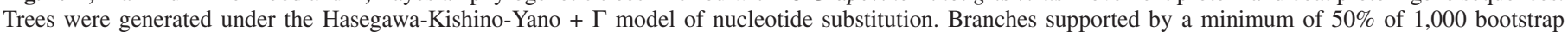

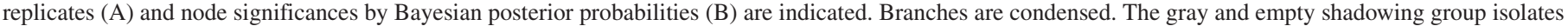
from symptomatic or symptomless vines, respectively. 
originating from symptomless vines, was obtained when the RdRp domain was analyzed (Fig. 5).

Prior to the phylogenetic analysis under a Bayesian framework, the existence of a temporal signal in our MP/CP sequence data was evaluated. A linear regression between the genetic distance from the root and the sampling time by using Path-O-Gene (not shown) yielded a correlation coefficient of 0.2635 , which is weakly indicative of a linear increase of nucleotide substitution over time. This very low value is plausible, considering the limited 5-year time period (2010 to 2014) of sampling. An MCC tree was obtained using the HKY best-fitting model of nucleotide substitution using the BEAST package. Phylogenetic clustering of MP/CP sequences confirmed the previously observed partitioning of GPGV isolates in two lineages that comprise the symptomatic and symptomless phenotypes, and this was supported by strong posterior probabilities (Fig. 4B). Similarly, the analysis of the RdRp region showed the same distinction, with the difference that clustering of the symptomatic isolates was, in this region, split into two branches, one of them containing the grapevine accessions MER(FA)1A ('Merlot') and BE(FA59)1A (Pinot noir) (Fig. 5B).

A careful observation of the aligned MP/CP sequences from GPGV isolates disclosed a polymorphism involving the MP stop codon TAA at position 6,684 of the GPGV IT genome sequence. Unlike the Slovak isolates GPGV SK01, SK13, and SK30, the isolate GPGV IT should have an MP that is 6 amino acids (aa) shorter, because of the T/C polymorphism involving this stop codon (Supplementary File S1). The alignment of all the MP/CP sequences revealed that the TAA stop codon is maintained in all but one isolate [ZA(PA)P2] originating from symptomatic vines which, consequently, have a 369-aa-long MP, whereas MPs of isolates from symptomless vines are 375 aa long. Presumably, the inconsistency of isolate ZA(PA)P2 is in line with its unresolved topology (Fig. 4A and $\mathrm{B})$. To find out whether the observed lineage distribution (i.e., symptomatic versus symptomless isolates) could be exclusively related to this $\mathrm{T} / \mathrm{C}$ polymorphism, this nucleotide was artificially changed in a set of 10 randomly chosen sequences from isolates either showing symptoms or not. The resulting altered alignment generated the same lineage distribution observed in phylogenetic analysis with real data. This test demonstrated that the T/C polymorphism is not solely responsible for lineage distinction but, more likely, is part of a more general GPGV phylodynamic behavior.
Field survey and virus frequency. Field surveys were done in several vineyards of Val d'Adige and Vallagarina for five consecutive seasons (2010 to 2014), which disclosed the presence of symptoms also on Merlot (Table 1). Collection from symptomless vines in the same vineyard showed that 75 of $92(82 \%)$ vines were infected with GPGV (Table 4). In this viticultural area, virus association with symptoms was found in 59 of 75 GPGV-infected vines (79\%). Conversely, 17 symptomless vines were negative for GPGV in RT-PCR. All tested vines were negative for viruses associated with grapevine leafroll, rugose wood, and infectious degeneration but were occasionally infected by GRSPaV or GFkV, with no consistent association with the disease (Table 1).

\section{DISCUSSION}

A series of common findings connotes this new grapevine disease, with which GPGV is associated in all viticultural areas of occurrence: (i) symptoms were first observed in 2001 in Slovenia (20) and 2003 in Trentino (7); (ii) the disease seems to spread and cause economic losses particularly in premium wine cultivars $(20,22)$; and (iii) wherever the disease occurs, no relevant grapevine viruses are associated with it, except for GPGV $(7,20)$ (http:// archives.eppo.int/EPPOReporting/2014/Rse-1401.pdf).

GPGV was also found in symptomless grapevines $(7,8)$ (http:// archives.eppo.int/EPPOReporting/2014/Rse-1401.pdf), raising doubts about its involvement in the disease, a behavior already reported for the close relative GINV (10). The disease emergence and spread support the recent occurrence of a new pathogen correlated with it that experimental evidence associates with the presence of GPGV, at least in the viticultural areas of Trentino. This conclusion is supported by the consistent association of GPGV with

TABLE 4. Survey of Grapevine Pinot gris virus (GPGV) association with symptoms in Trentino by reverse-transcription polymerase chain reaction

\begin{tabular}{|c|c|c|c|}
\hline Virus $^{a}$ & $\begin{array}{c}\text { Number of vines } \\
\text { with symptoms (\%) }\end{array}$ & $\begin{array}{c}\text { Number of } \\
\text { symptomless vines }(\%)\end{array}$ & Total \\
\hline GPGV + & $59(79)$ & $16(21)$ & 75 \\
\hline GPGV - & $0(0)$ & 17 (100) & 17 \\
\hline
\end{tabular}

a Presence or absence of the virus are indicated by + and - , respectively.
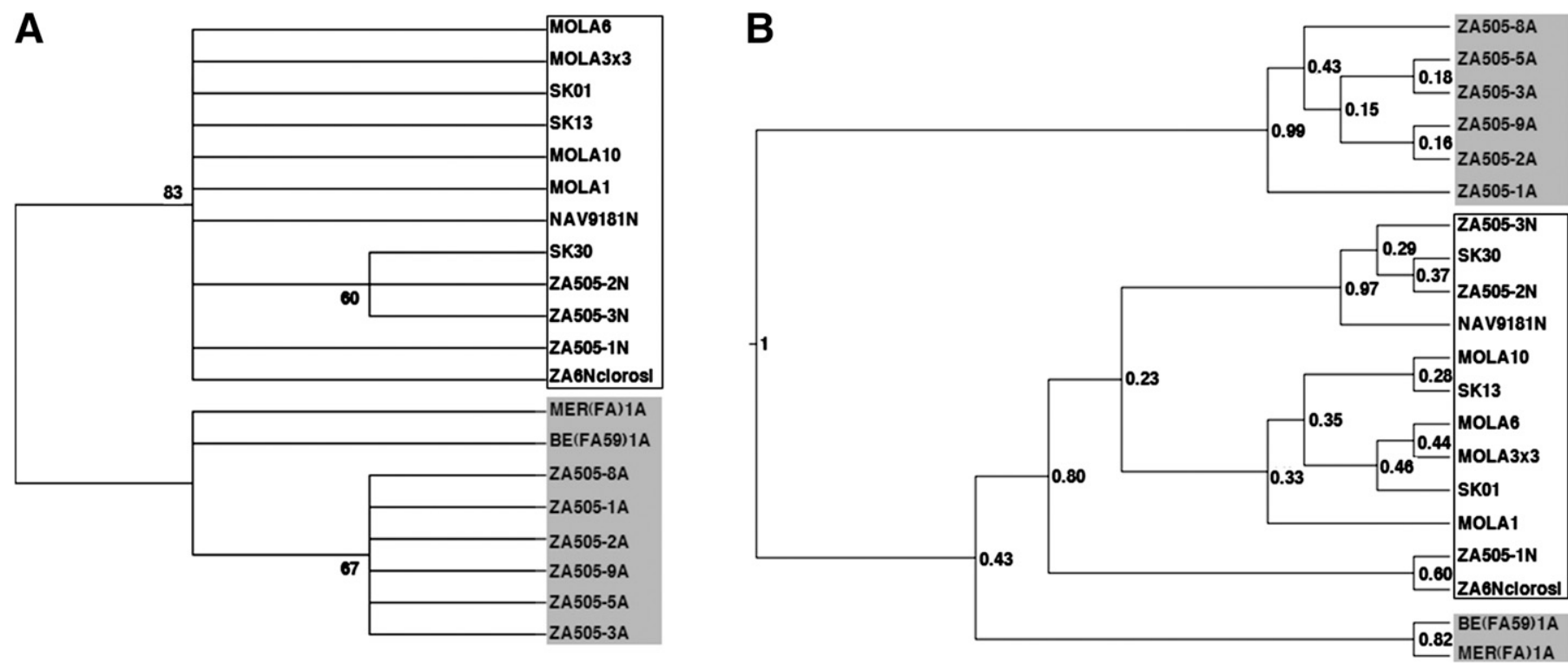

Fig. 5. A, Maximum likelihood and B, Bayesian phylogenetic trees inferred with 20 Grapevine Pinot gris virus RNA-dependent RNA polymerase sequences. Trees were generated under the Hasegawa-Kishino-Yano $+\Gamma$ model of nucleotide substitution. Branches supported by a minimum of $50 \%$ of 1,000 bootstrap replicates (A) and node significances by Bayesian posterior probabilities (B) are indicated. Branches are condensed. The gray and empty shadowing group isolates from symptomatic or symptomless vines, respectively. 
symptomatic but not symptomless vines and, more strongly, by the results of indexing that disclosed the existence of severe strains of the virus, pathogenic to Pinot gris and Traminer but not to the indicators Cabernet franc and V. rupestris. Both findings, together with multiple infections, likely explain the lack of association of GPGV with symptoms in Czech and Slovak vines (8).

NGS investigations further defined and confirmed the already known virome (7) and, in addition to excluding the existence of unknown viruses or viroids, allowed us to reassemble the almost complete genomic RNAs of three additional GPGV isolates from vines ZA505-2A, ZA505-1 N, and ZA505-2 N. Phylogenetic comparisons of available complete or consensus genomic RNAs delineate a "speciation" of symptomatic isolates ZA505-1A and ZA505-2A, whereas symptomless isolates from Trentino are grouped in a broader clade, together with those reported from the Slovak Republic. This observed GPGV evolutionary dynamic, indicating the existence of virulent and latent variants, was also confirmed by studies on a larger number of isolates in the MP/CP and RdRp genomic regions, in which two distinct genetic lineages grouping symptomless and symptomatic vines, respectively, were identified. Polymorphism in the MP stop codon confirms the GPGV tendency, already observed by Glasa et al. (8), to undergo an unusual nucleotide divergence and suggests a biological significance of this finding. The present investigations, in which the stop codon polymorphism was artificially modified, did not change the resulting topology, suggesting that it is part of a GPGV general evolutionary trend and not solely responsible for symptom association.

All these findings point toward the emergence of a new plant virus that underwent a recent evolution, whose origin is still obscure and will require further studies involving a larger number of samples. Factors that favor new virus disease emergence have been associated with ecological change or intensive agronomical practices (5), both common and frequent events occurring in some premium viticultural areas where GPGV was found. One of these factors consists of the recurrent renewal of vineyards with new cultivars to support market requests. Due to the continuous report of new GPGV detections in Italy and other European countries, a collaborative effort is requested to clarify its biology and epidemiology, taking into account that GINV, the other known grapevine trichovirus, is transmitted by mites.

\section{ACKNOWLEDGMENTS}

The research was supported by the Fondazione Edmund Mach, San Michele all'Adige (Trento), Italy, in the frame of the Project "Studio di una nuova malattia della vite in Trentino". A. Giampetruzzi was supported by a fellowship of the National Research Council, Project "CISIAValorizzazione delle risorse genetiche di colture mediterranee attraverso approcci di metagenomica, trascrittomica e analisi funzionale per la caratterizzazione di germoplasma autoctono, endofiti, agenti di biocontrollo e fitopatogeni (METAGERM)". We thank G. P. Martelli for critically reading and revising the manuscript.

\section{LITERATURE CITED}

1. Altschul, S. F., Madden, T. L., Schäffer, A. A., Zhang, J., Zhang, Z., Miller, W., and Lipman, D. J. 1997. Gapped BLAST and PSI-BLAST: A new generation of protein database search programs. Nucleic Acids Res. 25:3389-3402

2. Cho, I. S., Jung, S. M., Cho, J. D., Choi, G. S., and Lim, H. S. 2013. First report of Grapevine Pinot gris virus infecting grapevine in Korea. New Dis. Rep. 27:10.

3. Drummond, A. J., and Rambaut, A. 2007. BEAST: Bayesian evolutionary analysis by sampling trees. BMC Evol. Biol. 7:214.

4. Edgar, R. C. 2004. MUSCLE: Multiple sequence alignment with high accuracy and high throughput. Nucleic Acids Res. 32:1792-1797.

5. Elena, S. F., Fraile, A., and García-Arenal, F. 2014. Evolution and emergence of plant viruses. Adv. Virus Res. 88:161-191.
6. Gambino, G., and Gribaudo, I. 2006. Simultaneous detection of nine grapevine viruses by multiplex RT-PCR with coamplification of a plant RNA as internal control. Phytopathology 96:1223-1229.

7. Giampetruzzi, A., Roumi, V., Roberto, R., Malossini, U., Yoshikawa, N., La Notte, P., Terlizzi, F., Credi, R., and Saldarelli, P. 2012. A new grapevine virus discovered by deep sequencing of virus- and viroidderived small RNAs in cv Pinot gris. Virus Res. 163:262-268.

8. Glasa, M., Lukas, P., Komınek, P., Nagyova, A., Candresse, T., and Olmos, A. 2014. Molecular characterization of divergent grapevine Pinot gris virus isolates and their detection in Slovak and Czech grapevines. Arch. Virol. 159:2103-2107.

9. Hasegawa, M., Kishino, H., and Yano, T. 1985. Dating the human-ape splitting by a molecular clock of mitochondrial DNA. J. Mol. Evol. 22:160-174.

10. Kunugi, Y., Asari, S., Terai, Y., and Shinkai, A. 2000. Studies on the grapevine berry inner necrosis virus disease. 2 . Transmission of grapevine berry inner necrosis virus by the grape erineum mite Colomerus vitis in Yamanashi. Bull. Yamanashi Fruit Tree Exp. Stn. 10:57-63.

11. Li, R., Li, Y., Kristiansen, K., and Wang, J. 2008. SOAP: Short oligonucleotide alignment program. Bioinformatics 24:713-714.

12. MacKenzie, D. J., McLean, M. A., Mukerji, S., and Green, M. 1997. Improved RNA extraction from woody plants for the detection of viral pathogens by reverse transcription-polymerase chain reaction. Plant Dis. 81:222-226.

13. Malossini, G., Franco, G., Benvenuto, L., Massenta, M., Quagliano, G., Stocco, M., and Frausin, C. 2012. Lotta guidata in viticoltura: ERSAAgenzia regionale per lo sviluppo rurale della Regione Friuli Venezia Giulia. http://www.ersa.fvg.it/fitosanitaria/viticoltura/archivio-relazionisituazione-fitosanitaria-in-viticoltura/Viticoltura\%2030012013Def.pdf

14. Malossini, U., Moscon, R., Ferrazza, M., Bianchedi, P., Varner, M., and Credi, R. 2012. Caratteristiche vegeto-produttive di viti Pinot grigio e Traminer aromatico affette da una nuova virosi segnalata in Trentino. IV Convegno Nazionale di Viticoltura CONAVI.TO Asti, 10-11-12 luglio 2012 pp 37. http://www.unito.it/unitoWAR/ShowBinary/FSRepo/D046/ Allegati/CONAVI_2012/CONAVI_2012_Libro_dei_riassunti.pdf

15. Martelli, G. P. 2014. Directory of virus and virus-like diseases of the grapevine and their agents. J. Plant Pathol. 96(1S):110-111.

16. Martin, D. P., Lemey, P., Lott, M., Moulton, V., Posada, D., and Leveuvre, P. 2010. RDP3: A flexible and fast computer program for analyzing recombination. Bioinformatics 26:2462-2463.

17. Meng, B., Johnson, R., Peressini, S., Forsline, P. L., and Gonsalves, D. 1999. Rupestris stem pitting associated virus-1 is consistently detected in grapevines that are infected with rupestris stem pitting. Eur. J. Plant Pathol. 105:191-199.

18. Morelli, M., de Moraes Catarino, A., Susca, L., Saldarelli, P., Gualandri, V., and Martelli, G. P. 2014. First report of Grapevine Pinot gris virus from table grapes in Southern Italy. J. Plant Pathol. 96:439.

19. Pantaleo, V., Saldarelli, P., Miozzi, L., Giampetruzzi, A., Gisel, A., Moxon, S., Dalmay, T., Bisztray, G., and Burgyan, J. 2010. Deep sequencing analysis of viral short RNAs from an infected Pinot Noir grapevine. Virology 408:49-56.

20. Plesko, M. I., Marn, V. K., Seljak, G., and Zezlina, I. 2014. First report of Grapevine pinot gris virus infecting grapevine in Slovenia. Plant Dis. 98: 1014.

21. Prüfer, K., Stenzel, U., Dannemann, M., Green, R. E., Lachmann, M., and Kelso, J. 2008. PatMaN: Rapid alignment of short sequences to large databases. Bioinformatics 24:1530-1531.

22. Raiola, A., Scopel, C., Ferrigo, D., Taglietti, F., Duso, C., and Causin, R.2013. First report of Grapevine Pinot gris virus infecting cv. Glera in the Conegliano-Valdobbiadene area. Abstr. IXX Cong. Ital. Phytopathol. Soc. Padua. J. Plant Pathol. 95, (4, Suppl.):S4.58.

23. Stocks, M. B., Moxon, S., Mapleson, D., Woolfenden, H. C., Mohorianu, I., Folkes, L., Schwach, F., Dalmay, T., and Moulton, V. 2012. The UEA sRNA workbench: A suite of tools for analysing and visualizing next generation sequencing microRNA and small RNA datasets. Bioinformatics 28:2059-2061.

24. Tamura, K., Peterson, D., Peterson, N., Stecher, G., Nei, M., and Kumar, S. 2011. MEGA5: Molecular Evolutionary Genetics Analysis using Maximum Likelihood, Evolutionary Distance, and Maximum Parsimony Methods. Mol. Biol. Evol. 28:2731-2739.

25. Taylor, R. H., Woodham, R. C., and Allan, A. W. 1967. Green grafting: A useful technique for detecting grapevine viruses. Aust. J. Exp. Agric. Anim. Husb. 7:91-95.

26. Yoshikawa, N., Iida, H., Goto, S., Magome, H., Takahashi, T., and Terai, Y. 1997. Grapevine berry inner necrosis, a new trichovirus: Comparative studies with several known trichoviruses. Arch. Virol. 142:1351-1363.

27. Zerbino, D. R., and Birney, E. 2008. Velvet: Algorithms for de novo short read assembly using de Bruijn graphs. Genet. Res. 18:821-829. 